논에서 생육특성과 수량이 우수한 두과 사료작물 선발

김원호 · 이종경 · 박형수 · 황보순 · 임영철 · 지희정 · 이효원* · 윤봉기** · 서 성

\title{
Selection of Growth Characteristics and Yield of Annual Legumes on Paddy Field
}

Won Ho Kim, Joung Kyong Lee, Hyung Soo Park, Soon Hwangbo, Young Cheol Lim, Hee Chung Ji, Hyo Won Lee*, Bong Ki Yoon** and Sung Seo

\begin{abstract}
This experiment was conducted to compare the agronomic characteristics and productivity of induced annual legumes at paddy field of Cheonan and Naju from 2004 to 2006. Chinese milk vetch (wild type), crimson clover (C.V. Linkarus), forage pea (C.V. Austrian pea), hairy vetch (C.V. Oregon commen) were used in this study. At the Naju region, the earliest flowering on 2nd may was found in Chinese milk vetch, while the latest on 18th May in forage pea. Fresh, dry matter (DM) and crude protein (CP) yields of crimson clover were highest as $28,870,6,986$ and $943 \mathrm{~kg} / \mathrm{ha}$, respectively. but the yield of chinese milk vetch was low by 9,885, 1,749 and $338 \mathrm{~kg} / \mathrm{ha}$. At the Cheonan region, the most fast flowering date variety was Chinese milk vetch, hairy vetch was very late as 19th May. Fresh, DM and CP yields of hairy vetch were highest as $7,916,1,141$ and $113 \mathrm{~kg} / \mathrm{ha}$, respectively. but the yield of chinese milk vetch showed the lowest by 270,42 and $8 \mathrm{~kg} / \mathrm{ha}$. The CP content of annual legumes was $14.3 \%$. chinese milk vetch showed the highest CP content by $19.3 \%$ and hairy vetch showed the lowest content by $9.9 \%$. The present data showed that the productivity was closely dependent on winter hardness, in conclusion, crimson clover at Naju and hairy vetch at Cheonan region was suggested to be the most proper species as winter crop after rice harvest on paddy field when considered the winter hardiness.
\end{abstract}

(Key words : Forage production, Forage quality, Promising legume, Vicia sativa L.)

\section{I. 서 론}

근래 우리 농촌이 저비용 고소득의 방향으 로, 우리국토를 효율적으로 이용한다면 생산비 를 절감하고, 생산량을 높일 수 있는 기술의 개발과 현장접목이 좋은 해결방법이라 생각된 다. 또한 가축분뇨를 최대로 활용하는 자연순 환농법과 물질순환농업을 위해서는 축산과 경 종농업의 협력이 중요한 시기이며, 경종농가와
연계한 논에서 양질조사료 생산과 이용을 위해 여러 가지 정책이 수립되고 있다.

최근 푸른들 가꾸기와 농촌경관 개선, 토양 비옥도 증진을 위해 두과 사료작물의 재배가 늘어나고 있다. 자운영은 남부지역에 사료작물 보다는 녹지작물로 최근까지 많이 재배되었고 녹비효과도 큰 것으로 판단된다. 그리고 크림 손 클로버 (crimson clover)는 옥수수 후작 작물 로 우리나라에서도 재배가 가능하고 생산성도

\footnotetext{
농촌진흥청 국립축산과학원 (National Institute of Animal Science, RDA, Cheonan, 330-801, Korea)

* 한국방송통신대학교 (Dept. of Agricultural Science, Korea National Open. Seoul)

** 전남 농업기술원 (Jeollanam-Do Agricultural Research and Extension Services Naju, Korea)

Corresponding author: Kim Won Ho, National Institute of Animal Science, Korea, Tel: +82-41-580-6747, Fax: +82-41-580-6779, E-mail: kimhw@korea.kr
} 
우수하다 (김 등. 1994). Wagger (1989), Mitchel 등 (1977) 그리고 Touchton 등 (1982)은 크림손 클로버 초종이 질소고정량도 $43 \mathrm{~kg} / \mathrm{ha}$ 로 옥수수 생육시 유용하게 질소공급원으로 이용된다고 보고하였다.

베치류의 특징은 친환경 농업을 위한 Vicia 속 품종들이 녹비작물이나 양질조사료 확보 차 원에서 널리 재배되고 있으나 내한성의 차이와 (Barnes 등, 1995, Clark 등, 1995) 품종간 사료 가치와 생초 및 건물 생산성에 차이가 많아 논 에서 적응성이 우수한 품종선발이 시급한 실정 이다. 우리나라에서 베치류에 대한 연구는 경 북지역에서 도입품종과 자생종 베치류에 대한 품종비교가 있었으나 이를 중부지역까지 확대 하여 해석하기가 문제가 있을 것으로 보이며 (신, 2000), 베치류의 생산성은 월동성에 따라 많은 차이를 보여 월동성을 고려한 후에 베치 류의 도입이 고려되어야 할 것으로 보고하였다 (김, 2004).

그리고 질소 고정량이 많고 건물생산성이 우 수한 사료용 완두 (forage pea)는 남부지역 배수 가 양호한 논에서 10 월 상순에 파종하여 이듬 해 5월 중순에 수확하여 양질조사료로 이용이 가능하고, 베타카로틴과 비타민 $\mathrm{A}, \mathrm{C}$ 등이 풍 부한 작물로 보고하였다 (서 등, 2000).

따라서 본 연구에서는 논에서 생육특성과 수 량성 등을 고려하여 논에서 적응이 우수한 두 과 사료작물을 선발코자 수행되었다.

\section{․ 재료 및 방법}

본 시험은 국립축산과학원과 전남농업기술원 답리작 논에서 2004년 10월부터 2006년 5월까
지 수행하였으며, 두과 사료작물인 자운영, 크 림손 클로버, 사료용 완두 그리고 헤어리 베치 의 4 초종을 공시하였으며, 각각의 품종에서 자 운영은 국내에 자생하는 품종을 공시하였고, 크림손 클로버는 'Linkarus' 품종, 사료용 완두 는 'Austria pea' 품종 그리고 헤어리 베치는 'Oregen common' 품종을 공시하였다.

지역별 파종은 10 월 15 일 (천안) 경에 파종하 였고 10 월 18 일 (나주) 경에 파종하여 이듬해 5 월 18 일(천안)과 5 월 20 일(나주)에 수확하였다. 파종량은 자운영, 크림손 클로버, 헤어리 베치 는 ha당 $40 \mathrm{~kg}$ 으로 하였고 Forage pea는 120 $\mathrm{kg} / \mathrm{ha}$ 를 파종하였다. 시비량은 4초종 ha당 질소 $50 \mathrm{~kg}$, 인산 $120 \mathrm{~kg}$, 칼리 $120 \mathrm{~kg}$ 으로 이 중 질 소비료는 기비로 $25 \mathrm{~kg}$, 이른 봄 추비로 $25 \mathrm{~kg}$ 을 분시 하였으며, 인산과 칼리비료는 전량 기 비로 시용하였다. 시험구는 품종별로 난괴법 3 반복 배치하였으며, 시험구당 면적은 $12 \mathrm{~m}^{2}$ $(2.4 \times 5.0 \mathrm{~m})$ 였다.

화학분석을 위하여 수확당일 $300 \sim 500 \mathrm{~g}$ 의 시 료를 취하여 $65^{\circ} \mathrm{C}$ 순환식 송풍 건조기 내에서 72 시간 이상 건조한 후 건물 함량을 구하였고 얻어진 시료는 전기믹서로 1 차 분쇄 후 20 mesh mill로 다시 분쇄한 후 이중마개가 있는 플라스틱 시료통에 넣어 직사광선이 들지 않는 곳에 보관하여 분석에 이용하였다. 조단백질 함량은 AOAC (1990)법에 의거하여 분석하였고 $\mathrm{NDF}$ 및 ADF는 Goering 및 Van Soest법 (1970) 에 따랐으며 in vitro 건물소화율은 Tilley 및 Terry 법(1963)을 수정한 방법을 사용하였다. $\mathrm{TDN}$ 함량 $(88.9-\mathrm{ADF} \% \times 0.79)$ 은 계산식에 의해 서 산출하였다. 그리고 전남 나주와 충남 천안 의 시험포 토양특성은 농촌진흥청 토양화학분

Table 1. Soil characteristics of paddy field in Naju and Cheonan

\begin{tabular}{|c|c|c|c|c|c|c|c|c|}
\hline \multirow{2}{*}{ Region } & \multirow{2}{*}{$\begin{array}{l}\mathrm{pH} \\
(1: 5) \\
\end{array}$} & \multirow{2}{*}{$\begin{array}{l}\text { Organic } \\
\text { matter } \\
(\mathrm{g} / \mathrm{kg})\end{array}$} & \multirow{2}{*}{$\begin{array}{c}\text { Available } \\
\mathrm{P}_{2} \mathrm{O}_{5} \\
(\mathrm{mg} / \mathrm{kg})\end{array}$} & \multicolumn{3}{|c|}{$\begin{array}{c}\text { Exchangeable cation } \\
\left(\mathrm{cmol}^{+} / \mathrm{kg}\right)\end{array}$} & \multirow{2}{*}{$\begin{array}{c}\mathrm{CEC} \\
\left(\mathrm{cmol}^{+} / \mathrm{kg}\right) \\
\end{array}$} & \multirow{2}{*}{$\begin{array}{l}\mathrm{T}-\mathrm{N} \\
(\%) \\
\end{array}$} \\
\hline & & & & $\mathrm{K}$ & $\mathrm{Ca}$ & $\mathrm{Mg}$ & & \\
\hline Naju & 5.2 & 28.1 & 34 & 0.47 & 4.3 & 1.5 & 10.3 & 0.21 \\
\hline Cheonan & 5.8 & 18.0 & 21 & 0.66 & 5.7 & 1.4 & - & 0.33 \\
\hline
\end{tabular}


석법(1988)에 준하여 분석하였고 분석결과는 Table 1에 나타내었다.

\section{III. 결과 및 고찰}

1. 나주에서 두과 사료작물의 생육특성

논에서 적응성과 생산성이 우수한 두과 사료 작물을 선발하기 위해서 사용한 자운영 1 초종 과 두과 사료작물 3 초종에 대한 생육특성은 Table 2에서 나타내었다.

개화기는 자운영이 5월 2일로 가장 빠르고 사료용 완두가 5 월 18 일로 가장 늦었다. 초장 은 헤어리 베치에서 $101 \mathrm{~cm}$ 로 가장 크고 자운 영이 $27 \mathrm{~cm}$ 로 가장 작았다. 그리고 월동율은 크림손 클로버와 헤어리 베치에서 양호하였고 자운영과 사료용 완두에서는 비슷하였다. 신 등(2008)은 수원지역에서 헤어리 베치와 크림 손 클로버 초종을 비교한 결과 크림손 클로버 초종이 가장 컸었고 헤어리 베치와 사료용 완 두 초종도 양호하였다고 보고하였다. 그리고
서 등(2001)은 수원지역에서 헤어리 베치 초종 이 재배 및 이용측면에서 유리하다고 보고하 였다.

2. 나주에서 두과 사료작물의 생산성

나주지역 논에서 적응성이 우수한 두과 사료 작물을 선발하기 위해서 자운영 1 초종과 두과 사료작물 3 초종을 공시하여 건물률과 생산성 비교는 Table 3에서 나타내었다.

자운영보다는 크림손 클로버 초종이 건물률 이 높았고 두과 사료작물의 평균 건물률은 $21.1 \%$ 였다. ha당 생초수량은 크림손 클로버 초 종이 $28,870 \mathrm{~kg} / \mathrm{ha}$ 으로 가장 많았고 자운영에서 가장 낮았다. 그리고 사료용 피와 헤어리 베치 초종에서도 생초수량이 양호하였다. 또한 건물 수량에 있어서도 크림손 클로버 초종이 많았고 자운영에서 가장 적었다. 그리고 조단백질 (CP) 수량은 크림손 클로버 초종에서 943 $\mathrm{kg} / \mathrm{ha}$ 로 가장 많았고 자운영에서 $338 \mathrm{~kg} / \mathrm{ha}$ 로 가장 적었다.

Table 2. Growth characteristics of annual legumes on paddy field of Naju

\begin{tabular}{lcccc}
\hline \multicolumn{1}{c}{ Species } & $50 \%$ Flowering & $\begin{array}{c}\text { Plant length } \\
(\mathrm{cm})\end{array}$ & $\begin{array}{c}\text { Winter-hardy } \\
(1-9)^{*}\end{array}$ & $\begin{array}{c}\text { Lodging } \\
(1-9)^{*}\end{array}$ \\
\hline \hline Chinese milk vetch & 2 May & 27 & 8 & 1 \\
Crimson clover & 5 May & 52 & 4 & 1 \\
Forage pea & 18 May & 68 & 7 & 1 \\
Hairy vetch & 12 May & 101 & 5 & 1 \\
\hline
\end{tabular}

* 1 : Expellant or strong, 9 : Worst or weak.

Table 3. Productivity of annual legumes on paddy field of Naju region

\begin{tabular}{lcccc}
\hline \multirow{2}{*}{ Species } & Dry matter & \multicolumn{3}{c}{ Yield(kg/ha) } \\
\cline { 3 - 4 } & percentage(\%) & Fresh & Dry matter & CP \\
\hline \hline Chinese milk vetch & 17.7 & 9,885 & 1,749 & 338 \\
Crimson clover & 24.2 & 28,870 & 6,986 & 943 \\
Forage pea & 20.9 & 26,880 & 5,617 & 809 \\
Hairy vetch & 21.6 & 25,030 & 5,406 & 535 \\
\hline \multicolumn{1}{c}{ Mean } & 21.1 & 22,666 & 4,939 & 656 \\
\hline
\end{tabular}




\section{3. 천안에서 두과 사료작물의 생육특성}

천안지역 논에서 적응성이 우수한 두과 사료 작물을 선발하기 위해서 4 초종을 공시하여 수 행한 결과 생육특성에 대한 결과는 Table 4에 서 보는 바와 같다.

천안지역 논에서 재배한 두과 사료작물의 개 화기는 크림손 클로버에서 5 월 6 일로 가장 빠 르고 헤어리 베치에서 5월 19일로 가장 늦었 다. 그러나 월동율은 헤어리 베치 초종에서 가 장 좋았고 자운영에서 가장 낮았다. 그리고 초 장은 헤어리 베치 초종에서 $71 \mathrm{~cm}$ 로 가장 크고 자운영에서 $16 \mathrm{~cm}$ 로 가장 적었다. 도복은 4초 종 간에서 모두 적었다.

\section{4. 천안에서 두과 사료작물의 생산성}

천안지역 논에서 적응성이 우수한 두과 사료 작물을 선발하기 위해서 4 초종을 공시하여 수 행한 결과 생산성은 Table 5 에서 나타내었다.
중부지역 천안 논에서 적응성이 우수한 두과 사료작물의 건물률은 평균 17.6 였다. 이중 건물 률이 높은 것은 크림손 클로버 초종이 $26.2 \%$ 로 높았고 자운영에서 $13.2 \%$ 로 가장 낮았다. 그리 고 생초수량은 헤어리 베치 초종에서 7,916 $\mathrm{kg} / \mathrm{ha}$ 로 가장 많았고 자운영은 거의 없었다. 건 물수량은 생초수량이 비슷한 경향이었고 사료 용 완두 초종에서 양호한 결과를 얻었다. 그러 나 자운영과 크림손 클로버 초종에서 건물수량 이 낮았다. 또한 조단백질 수량은 헤어리 베치 초종에서 $113 \mathrm{~kg} / \mathrm{ha}$ 으로 가장 많았으나 나주지 역에 비교해서 현저하게 낮았다. 특히 나주지 역보다 수량이 현저히 떨어지는 원인으로는 천 안지역이 겨울철 온도가 낮아 두과 사료작물 월동률이 낮은 것이 주원인으로 사료된다.

김 (1994)은 수원에서 크림손 클로버와 헤어 리 베치를 비교한 결과 크림손 클로버에서 건 물수량이 $4,779 \mathrm{~kg} / \mathrm{ha}$ 로 많았고 헤어리 베치는 $2,569 \mathrm{~kg} / \mathrm{ha}$ 로 낮았다. 이는 월동률과 밀접한 관 계가 있어 봄에 초기 생육이 크림손 클로버에 서 좋았다. 본 연구에서는 크림손 클로버보다

Table 4. Growth characteristics of annual legumes on paddy field of Cheonan

\begin{tabular}{lcccc}
\hline \multicolumn{1}{c}{ Species } & $50 \%$ Flowering & $\begin{array}{c}\text { Plant length } \\
(\mathrm{cm})\end{array}$ & $\begin{array}{c}\text { Winter-hardy } \\
(1-9)^{*}\end{array}$ & $\begin{array}{c}\text { Lodging } \\
(1-9)^{*}\end{array}$ \\
\hline \hline Chinese milk vetch & 8 May & 16 & 8 & 1 \\
Crimson clover & 6 May & 52 & 5 & 1 \\
Forage pea & 15 May & 40 & 7 & 1 \\
Hairy vetch & 19 May & 71 & 4 & 2 \\
\hline
\end{tabular}

* 1(Excellant or strong), 9 (Worst or weak)

Table 5. Productivity of vetch cultivates on paddy field of Cheonan

\begin{tabular}{lcccc}
\hline \multirow{2}{*}{ Species } & Dry matter & \multicolumn{3}{c}{ Yield(kg/ha) } \\
\cline { 3 - 5 } percentage(\%) & Fresh & Dry matter & CP \\
\hline \hline Chinese milk vetch & 13.2 & 270 & 42 & 8 \\
Crimson clover & 26.2 & 1,100 & 288 & 39 \\
Forage pea & 14.6 & 4,277 & 626 & 90 \\
Hairy vetch & 16.2 & 7,916 & 1,141 & 113 \\
\hline \multicolumn{1}{c}{ Mean } & 17.6 & 3,391 & 524 & 63 \\
\hline
\end{tabular}


Table 6. Chemical composition of annual legumes on paddy field

\begin{tabular}{lccccc}
\hline \multicolumn{1}{c}{ Species } & $\begin{array}{c}\text { CP } \\
(\%)\end{array}$ & $\begin{array}{c}\text { IVDMD } \\
(\%)\end{array}$ & $\begin{array}{c}\text { ADF } \\
(\%)\end{array}$ & $\begin{array}{c}\text { NDF } \\
(\%)\end{array}$ & $\begin{array}{c}\text { TDN } \\
(\%)\end{array}$ \\
\hline \hline Chinese milk vetch & 19.3 & 59.3 & 36.2 & 47.1 & 60.3 \\
Crimson clover & 13.5 & 58.0 & 38.9 & 51.0 & 58.2 \\
Forage pea & 14.4 & 74.3 & 23.2 & 40.3 & 70.4 \\
Hairy vetch & 9.9 & 60.1 & 31.6 & 44.8 & 63.9 \\
\hline \multicolumn{1}{c}{ Mean } & 14.3 & 62.9 & 32.5 & 45.8 & 63.2 \\
\hline
\end{tabular}

헤어리 베치에서 건물수량이 많은 것은 월동력 이 우수한 헤어리 베치 품종이 도입된 것으로 사료된다.

또한 김 등 (2004)은 수원지역 밭에서 베치 류 5 품종을 공시하여 3 년간 시험한 결과 크림 손 클로버와 헤어리 베치 품종이 $8,664 \mathrm{~kg} / \mathrm{ha}$ 으 로 가장 많았다고 하였으며, 파종시기는 9 월 15 일로 베치류의 건물수량은 파종시기와 밀접 한 관계가 있다고 보고하였다. 따라서 본 연구 에서는 벼 수확후 베치류와 작부체계로 파종 시기를 10 월 15 일경으로 앞으로 9 월 파종할 수 있는 입모종 등 다양한 연구가 필요하다고 사료된다.

\section{5. 논에서 두과 사료작물의 사료가치}

나주지역과 천안지역 논에서 재배되었던 두 과 사료작물의 사료가치는 Table 6에서 보는 바와 같다. 조단백질 함량은 자운영에서 $19.3 \%$ 로 가장 높았고 헤어리 베치 초종에서 $9.9 \%$ 로 가장 낮았다. 크림손 클로버와 Forage pea 초종 에서는 비슷하였다. 신 등(2000)은 자운영 1 품 종과 베치류 7 품종을 공시하여 8 월에 파종하여 이듬해 5월에 수확한 결과 자운영보다 헤어리 베치에서 조단백질 함량이 높았다고 보고하였 으며, 김 등(2004)의 보고에서도 비슷한 결과를 얻었다. 그러나 본 연구결과에서는 헤어리 베 치보다 자운영에서 높게 나타났으며, 이는 수 확시 헤어리 베치가 고사되여 앞으로 이에 대
한 연구를 지속적으로 수행할 필요가 있을 것 으로 사료된다.

$$
\text { V. 요 약 }
$$

본 연구는 논에서 생육특성과 생산성이 우수 한 두과 사료작물을 선발하기 위해서 천안(국 립축산과학원)과 나주 (전남도농업기술원) 답리 작 논에서 2004부터 2006년까지 수행되었다. 두과 사료작물은 자운영, 크림손 클로버, 사료 용 완두 그리고 헤어리 베치 초종을 공시하였 고 각 초종의 품종은 자운영에서 국내에서 자 생하는 품종(야생종)과 크림손 클로버 (C.V. Linkarus), 사료용 완두 (C.V. Austroan pea), 헤 어리 베치 (C.V. Oregon common)을 각각 공시 하였다. 나주지역에서 수행되었던 두과 사료작 물의 개화기는 자운영이 가장 빠르고 Forage pea 초종이 가장 늦었다. 크림손 클로버 초종 의 생초, 건물 그리고 조단백질 수량은 각각 $28,870,6,986$ 그리고 $943 \mathrm{~kg} / \mathrm{ha}$ 으로 가장 많았 다. 그러나 자운영에서는 $9,885,1,749$ 그리고 $338 \mathrm{~kg} / \mathrm{ha}$ 으로 가장 적었다. 천안지역 논에서는 자운영이 가장 빠르고 헤어리 베치 초종에서 가장 늦었다. 헤어리 베치 초종의 생초, 건물 그리고 조단백질 수량은 각각 7,916, 1,141 그 리고 $113 \mathrm{~kg} / \mathrm{ha}$ 으로 가장 많았고 자운영에서 270,42 그리고 $8 \mathrm{~kg} / \mathrm{ha}$ 으로 가장 적었다. 조단 백질 함량은 평균 $14.3 \%$ 로 높았고 자운영에서 $19.3 \%$ 로 가장 높았으나 헤어리 베치 초종에서 
$9.9 \%$ 로 가장 낮았다. 따라서 논에서 생육특성 과 수량을 고려한 결과 나주지여에서는 크림손 클로버 초종이 우수하고 천안지역에서는 헤어 리 베치 초종이 우수하였다.

\section{VI. 인 용 문 헌}

1. 김원호. 1994. 작물의 잔주와 그 관리가 사일리 지용 옥수수의 생장, 수량 및 사료가치에 미치는 영향. 서울대학교 박사학위 논문.

2. 김종근, 정의수, 임영철, 서 성, 김맹중, 김종덕. 2004. 도입 베치의 품종에 따른 생육특성 및 생 산성 비교 연구. 한초지. 24(2):177-182.

3. 서종호, 이호진, 허일봉, 김시주, 김충국, 조현숙. 2000. 동계 녹비작물 초종별 화학성분 및 생산성 비교. 한초지. 20(3):193-198.

4. 서종호, 이호진, 허일봉, 김시주. 2001. 헤어리벳 치의 추파시기에 따른 녹비의 수량 및 질소량의 변화. 한국작물학회지. 45(6):400-404.

5. 신정남, 김동암, 고기환, 김용원. 2000. 도입 베치 품종 및 한국 야생종의 생육특성과 수량. 한초 지. 20(4):251-258.

6. 신재순, 김원호, 윤세형, 임영철, 임근발, 서 성. 2008. 중부지역 논에서 월령생 두과 사료작물의 생육특성 및 수량비교. 초지조사료지. 28(1):1318.

7. 토양화학분석법. 1988. 농촌진흥청.

8. AOAC. 1995. Official methods of analysis. (16th ed.). Association of Official Analytical Chemists. Arlington, Virginia.
9. Barnes, R.F., D.A. Miller, and C.J. Nelson. 1995. Forage : Vol. I. An introduction to grassland agriculture (5th ed.). Iowa State University Press. Iowa.

10. Clark, A.J., A.M. Decker, J.J. Meisinger, F.R. Mulford and M.S. McIntosh. 1995. Hairy vetch kill date effects on soil water corn production systems. Agron. J. 87:579-585.

11. Goering, H.K. and P.J. Van Soest. 1970. Forage fiber analysis. Agric. Handb. 379, U. S. Gov. Print. Office, Washington, DC. Moore, J. E. 1970. Procedure for the two-stage in vitro digestion of forage. University of Florida, Department of Animal Science.

12. Mitchell, W.H., and M.R, Teel. 1977. Winter annual cover for no-tillage corn production. Agron. J. 69:569-571.

13. Tilley, J.M.A. and R.A. Terry. 1963. A two-stage technique for in vitro digestion of forage crops. J. Bri. Grassl. Soc. 18:119-128.

14. Touchton, J.T., W.A. Gardner, W. L. Hargrove, and R.R. Duncacan. 1982. Reseeding crimson clover as a $\mathrm{N}$ source for no-tillage pain sorghum production. Agro. J. 742:283-287.

15. Wagger, M.G. 1989. Time of desiccation effects on plant composition and subsequent nitrogen release several winter annual crops. Agro. J. 81:236-241.

(접수일: 2009년 10월 20일, 수정일 1차: 2009년 10 월 30일, 수정일 2차: 2009년 11월 5일, 게재확정일: 2009년 11월 17일) 